\title{
International Contractual Relationships: Transnational Approach
}

\author{
Dr. Esha Jain ${ }^{1}$, Mr. Ashank Yadav ${ }^{2}$ \\ ${ }^{1,2}$ GD Goenka University, Gurgaon, India.
}

\begin{abstract}
From the ancient law of Lex Mercatoria, which was an unwritten law followed by all the international traders and merchant of medieval times: International trade and commerce evolved to a newer system of laws in forms of conventions and treaties, binding as well as non-binding over nations worldwide. Since that evolving we reached to a few modern day international commercial laws: Modern trade law began shortly after the Second World War, with the negotiation of a multilateral treaty to deal with trade in goods that was known as the General Agreement on Tariffs and Trade (GATT). The research article focuses over different kinds of international commercial contractual relationships and their enforceability. It talks about different international commercial laws formed by international originations such as WTO, ICC and UNCITRAL. It also discusses the positive and negative comparisons point of the existence of such transnational contractual relationships in brief.
\end{abstract}

Keywords: Conventions, International Contracts, Law of Lex Mercatoria.

JEL Classification: K12, K22, K33.

\section{International commercial contracts}

\section{Introduction}

International commercial contracts are sale transaction agreements made between parties from different countries (Emery, 2016). International contract law concerns with the legal rules relating to cross-border agreements. When parties from different countries enter into a contract, they are governed by this type of law unless they agree to abide by the laws of one of the countries (Gilligan \&Hird,2012). It is frequently applied to international sales contracts. This type of contract law is broadly based on the idea of good faith and fair dealing in contracts. These principles are the basis of contract law in most jurisdictions. Good faith includes fair negotiations, an obligation to cooperate and good faith when terminating a contract. It also ensures that unfair contracts or deals are not enforced.

There are several methods of entering into international contracts these could be for example exporting directly; use of foreign agent to sell and distribute; use of foreign distributor to on-sell to local customers; manufacture products in the foreign country by either setting up business or by acquiring a foreign subsidiary; license to a local producer; enter into a joint venture with a foreign entity; appoint a franchisee in the foreign country or convention on the International Sale of Goods. One key element of international contract law includes the provision that the party's nationality does not play any role when applying the law, thereby placing all parties on an equal playing field. Rules of the contracts are interpreted by what a reasonable person would consider fair and appropriate given the circumstances. International contract law is a branch of private international law, which relates to the cross-border dealings of individuals or companies. This differs from public international law, which concerns the interaction between governments and other state agencies. Historically, merchants developed their own sort of international contract law. Traders wanting to deal despite differences in language, culture and laws developed their own code for international dealings. These rules have evolved into the good faith contract laws of today. Laws covering trade between businesses in different countries have existed since the law merchant was born in the medieval period. As business has grown across national borders and business relations have deepened, the legal dimension of business has had to follow suit. All commercial transactions across borders exist within the framework of national legal systems.In the carriage of goods by sea, air or land, goods may be lost, damaged or deteriorated (Schmitthoff, 1961).Moving to the bill of lading (transport document used almost exclusively for carriage of goods by sea) is a contract of carriage between the consignor, the carrier and consignee that acts as a receipt of transfer of goods and as a negotiable instrument (Levi, 2009). The bill of lading also determines rights and liabilities agreed between parties to an international sale contract. Also reservations as to the quality and quantity of the goods are marked on the bill when accepting goods so as to stifle any accusations from the consignee of damage in transit. The consignor retains ownership of the goods until the bill of lading is transferred to the consignee. Most bills of lading today are governed by international conventions such as the Hague Rules, Hague-Visby Rules and Hamburg Rules. These rules impose minimum responsibilities and liabilities that cannot be softened by contract (Buckley, 2004). 


\section{Payment In International Trade}

Two broad methods of financing international transactions are direct payment between seller and buyer; or finance through banks. Practically, payment is effected by the following methods:

- Cash in Advance: buyer transfers funds to the seller's account in advance pursuant to the sale contract.

- Open Account: arrangement for the buyer to advance funds to an 'open account' of the seller on a fixed date or upon the occurrence of a specified event, such as delivery of the goods.

- Bills of Exchange: negotiable instrument representing an order to the bank in writing to pay a certain sum of money to the bearer (or specified person) on demand, or at a fixed or determinable future time.

- Documentary Bill: seller (drawer) draws a bill of exchange on the buyer (drawee) and attaches it to the bill of lading. The idea is to secure acceptance of the bill of exchange by the buyer; and the buyer is bound to return the bill of lading if he does not honor the bill of exchange.

- Documentary Credits: the bank, on behalf of buyer, issues a letter of credit undertaking to pay the price of the sale contract on condition that the seller complies with credit terms. Upon presentation of necessary commercial documents verifying shipment of goods, the bank collects payment for goods on behalf of the seller. In the collection process, the buyer pays for goods in exchange for title documents. Under this method the bank guarantees the buyer's title to the goods and guarantees payment to the seller.

\section{Evolution Of International Commercial Law}

The body of rules for transnational trade in the $21^{\text {st }}$ century derives from medieval commercial laws called the Lex Mercatoriaand Lex Maritimarespectively, "the law for merchants on land" and "the law for merchants on sea." Modern trade law began shortly after the Second World War, with the negotiation of a multilateral treaty to deal with trade in goods that was known as the General Agreement on Tariffs and Trade (GATT) (World Trade Organization, 1986). International trade law today is based on theories of economic liberalism developed in Europe and later the United States from the 18th century onwards. International Trade Law is an aggregate of legal rules of "International Legislation" and new Lex Mercatoria, regulating relations in international trade.

Lex mercatoria (Latin for "merchant law") is the body of commercial law used by merchants throughout Europe during the medieval period (Ziegel, 1998). It is a law which is unwritten, including customary commercial law; customary rules of evidence and procedure; and general principles of commercial law. It evolved similar to English common law as a system of custom and best practice, which was enforced through a system of merchant courts along the main trade routes. It functioned as the international law of commerce. It emphasized contractual freedom and alienability of property, while shunning legal technicalities and deciding cases ex aequoet bono (Latin for "from equity and conscience"). International commercial law today owes some of its fundamental principles to the Lex Mercatoria (Gessner \&Budak, 1998). This includes choice of arbitration institutions, procedures, applicable law and arbitrators, and the goal to reflect customs, usage and good practice among the parties (Lista, 2016).Lex Mercatoria precepts have been reaffirmed in new international mercantile law. National trade barriers are torn down in order to induce commerce. The new commercial law is grounded on commercial practice directed at market efficiency and privacy. Dispute resolution have also evolved, and functional methods like international commercial arbitration is now available. These developments have also attracted the interest of empirical sociology of law. The principles of the medieval Lex Mercatoriai.e. efficiency, party autonomy, and choice of arbitrator are applied, and arbitrators often render judgments based on customs. The new merchant law encompasses a huge body of international commercial law. International Trade Law includes the appropriate rules and customs for handling trade between countries. However, it is also used in legal writings as trade between private sectors, which is not right. This branch of law is now an independent field of study as most governments has become part of the world trade, as members of the World Trade Organization (WTO). Since the transaction between private sectors of different countries is an important part of the WTO activities, this latter branch of law is now a very important part of the academic works and is under study in many universities across the world. International Commercial Law is a body of legal rules, conventions, treaties, domestic legislation and commercial customs or usages that governs international commercial or business transactional sale transactions. A transaction will qualify to be international if elements of more than one country are involved (Pryles et al., 2004).

\section{Conventions And Their Significance Uncitral}

UNCITRAL (United Nations Commission on International Trade Law) is the core legal body of the United Nations system in the field of international trade law (Erdem, 1991). A legal body with universal membership specializing in commercial law reform worldwide for over 40 years, its business is the modernization and harmonization of rules on international business. Trade means faster growth, higher living standards, and new opportunities through commerce. In order to increase these opportunities worldwide, UNCITRAL is formulating modern, fair, and harmonized rules on commercial transactions. UNCITRAL's 
original membership comprised 29 states, and was expanded to 36 in 1973, and again to 60 in 2004 . UNCITRAL carries out its work at annual sessions held alternately in New York City and Vienna. Member states of UNCITRAL are representing different legal traditions and levels of economic development, as well as different geographic regions. The methods of work are organized at three levels. The first level is UNCITRAL itself (The Commission), which holds an annual plenary session. The second level is the intergovernmental working groups which develops the topics on UNCITRAL's work program. Texts designed to simplify trade transactions and reduce associated costs are developed by working groups comprising all member States of UNCITRAL, which meet once or twice per year. Non-member States and interested international and regional organizations are also invited and can actively contribute to the work since decisions are taken by consensus, not by vote. Draft texts completed by these working groups are submitted to UNCITRAL for finalization and adoption at its annual session. The International Trade Law Division of the United Nations Office of Legal Affairs provides substantive secretariat services to UNCITRAL, such as conducting research and preparing studies and drafts. This is the third level, which assists the other two in the preparation and conduct of their work. The key objectives of UNCITRAL are as follows:

- Updated information on case law and enactments of uniform commercial law

- Technical assistance in law reform projects

- Regional and national seminars on uniform commercial law

- Coordinating the work of organizations active and encouraging cooperation among them.

- Promoting wider participation in existing international conventions and wider acceptance of existing model and uniform laws.

- Preparing or promoting the adoption of new international conventions, model laws and uniform laws and promoting the codification and wider acceptance of international trade terms, provisions, customs and practice, in collaboration, where appropriate, with the organizations operating in this field.

- Promoting ways and means of ensuring a uniform interpretation and application of international conventions and uniform laws in the field of the law of international trade.

- Collecting and disseminating information on national legislation and modern legal developments, including case law, in the field of the law of international trade.

- Establishing and maintaining a close collaboration with the UN Conference on Trade and development.

- Maintaining liaison with other UN organs and specialized agencies concerned with international trade.

\section{United Nations Convention on Contracts for the International Sale of Goods (CISG)}

The United Nations Convention on Contracts for the International Sale of Goods (CISG; the Vienna Convention) (Felemegas, 2000) is a treaty that is a uniform international sales law. As of September 2014, it has been ratified by 83 countries that account for a significant proportion of world trade, making it one of the most successful international uniform laws. The CISG was developed by the United Nations Commission on International Trade Law (UNCITRAL), and was signed in Vienna in 1980. It came into force as a multilateral treaty on 1 January 1988, after being ratified by 11 countries. International sales contracts are governed by the United Nations Convention on Contracts for the International Sale of Goods (CISG) since 1980. The convention was developed in the hopes of promoting international trade by developing a global set of rules for contracts. The convention is a compromise between legal systems of common law, civil law and socialist law. The United Nations Convention on Contracts for the International Sale of Goods (CISG) is the main convention for international sale of goods. Established by UNCITRAL, the Convention governs the conclusion of the sale contract; and buyer and seller obligations, including respective remedies. It is not concerned with the validity or provisions of the contract nor its effect on the property sold. The importance of CISG is its interpretation. International context, uniformity and observance of good faith must be regarded when interpreting the Convention. Matters not expressly settled by CISG are to be determined according to the general principles of CISG; or in such absence, according to rules of private international law. The UNIDROIT Principles on International Commercial Contracts also provide a 'gap-filling' role to supplement CISG, so long as it supports a principle deduced from the Convention.

The CISG allows exporters to avoid choice of law issues, as the CISG offers "accepted substantive rules on which contracting parties, courts, and arbitrators may rely". Unless excluded by the express terms of a contract, the CISG is deemed to be incorporated into (and supplant) any otherwise applicable domestic laws with respect to a transaction in goods between parties from different Contracting States. The CISG has been regarded as a success for the UNCITRAL, as the Convention has been accepted by states from "every geographical region, every stage of economic development and every major legal, social and economic system" (Felemegas, 2000). Countries that have ratified the CISG are referred to within the treaty as "Contracting States". Of the uniform law conventions, the CISG has been described as having "the greatest influence on the law of worldwide trans-border commerce" (Schlechtriem, 2005). It has been described as a great legislative achievement, (Lookofsky, 1991) and the "most successful international document so far" in unified international 
sales law (Zeller, 2008), in part due to its flexibility in allowing Contracting States the option of taking exception to certain specified articles. This flexibility was instrumental in convincing states with disparate legal traditions to subscribe to an otherwise uniform code. A number of countries that have signed the CISG have made declarations and reservations as to the treaty's scope.

\section{Incoterms}

Incoterms 2010 refers to the newest collection of essential international commercial and trade terms. The Incoterms rules or International Commercial Terms are a series of pre-defined commercial terms published by the International Chamber of Commerce (ICC). The terms were devised in recognition of non-uniform standard trade usages between various States. When incorporated into a sale contract, the Incoterm code provides a detailed interpretation of rights and obligations between parties. They are widely used in International commercial transactions or procurement processes. A series of three-letter trade terms related to common contractual sales practices, the Incoterms rules are intended primarily to clearly communicate the tasks, costs, and risks associated with the transportation and delivery of goods. The Incoterms (Shipping) rules are accepted by governments, legal authorities, and practitioners worldwide for the interpretation of most commonly used terms in international trade. They are intended to reduce or remove altogether uncertainties arising from different interpretation of the rules in different countries. As such they are regularly incorporated into sales contracts worldwide.

Incoterms 2010 is the eighth set of pre-defined international contract terms published by the International Chamber of Commerce, with the first set having been published in 1936. Incoterms 2010 defines 11 rules, down from the 13 rules defined by Incoterms 2000. Four rules of the 2000 version ("Delivered at Frontier", DAF; "Delivered Ex Ship", DES; "Delivered Ex Quay", DEQ; "Delivered Duty Unpaid", DDU), replaced by two new rules ("Delivered at Terminal", DAT; "Delivered at Place", DAP) in the 2010 rules. In the prior version, the rules were divided into four categories, but the 11 pre-defined terms of Incoterms 2010 are subdivided into two categories based only on method of delivery. The larger group of seven rules may be used regardless of the method of transport, with the smaller group of four being applicable only to sales that solely involve transportation by water where the condition of the goods can be verified at the point of loading on board ship. They are therefore not to be used for containerized freight.

Any given Incoterm, in most jurisdictions, will not be incorporated into a contract without express or implied reference to it being an Incoterm. They are standardized and published, available for incorporation into international sale contracts at the parties' discretion. Parties should specifically refer to the Incoterms in the sale contract to indicate incorporation. The International Chamber of Commerce (ICC) is responsible for revising Incoterms periodically to reflect changing practices in international trade.

\section{World Trade Organization (WTO)}

In 1995, the World Trade Organization, a formal international organization to regulate trade, was established. It had been the most important development in the history of international trade law. The World Trade Organization (WTO) is an intergovernmental organization which regulates international trade. The WTO officially commenced on 1 January 1995 under the Marrakech Agreement, signed by 123 nations on 15 April 1994, replacing the General Agreement on Tariffs and Trade (GATT), which commenced in 1948. The WTO deals with regulation of trade between participating countries by providing a framework for negotiating trade agreements and a dispute resolution process aimed at enforcing participants' adherence to WTO agreements, which are signed by representatives of member governments: and ratified by their parliaments (Fernando, 2011) Most of the issues that the WTO focuses on derive from previous trade negotiations, especially from the Uruguay Round (1986-1994) (Meltzer, 2011).

The World Trade Organization supersedes the General Agreement on Tariffs and Trade (GATT) as the organization dealing with international trade and it provides a common institutional framework for trade relations between contracting parties (Van den Bossche, 2008). It represents a crucial aspect of international commercial law through its objectives of facilitating global trade flow, liberalizing trade barriers and providing an effective dispute settlement mechanism.

Major functions of the WTO include to:

- Provide framework for administration and implementation of agreements.

- Promote greater coherence among member's economics policies.

- Provide a forum for negotiating trade-related issues; and issues arising from the WTO Agreement.

- Provide a dispute settlement mechanism pursuant to the Understanding on Rules and Procedures Governing the Settlement of Disputes (DSU).

- Administer the Trade Policy Review Mechanism (TPRM) which examines the trade policies of members.

- Cooperate with the International Monetary Fund (IMF) and the International Bank for Reconstruction and Development (IBRD). 
GATT 1994 is incorporated into the WTO Agreement, and contains three important basic principles in the context of international commercial law:

- Most-favored nation principle (MFN): expresses that any advantage to a product originating or destined for another country shall be treated in accordance with a like product originating in or destined for the contracting country. Each GATT member must treat all trading partners as well as its most favored trading partner.

- "National treatment principle"': prohibits discrimination between imported and like domestic products, other than through the imposition of tariffs. The WTO panels consider tariff classifications, product nature, intended use, commercial value, price and sustainability.

- Reciprocity principle: encourages negotiations between contracting parties on a reciprocal and mutually advantageous basis, directed towards the reduction of tariffs and other charges on imports and exports.

\section{International contracts relating to intellectual property (IP)}

Developments in international trade through e-commerce have seen an increased emphasis on IP protection. The Agreement on Trade-Related Aspects of Intellectual Property Rights (TRIPS), which replaces earlier international IP agreements, outlines rules to control anti-competitive practices in international licenses relating to IP. TRIPS enables compliance disputes to be brought to attention of the WTO. Further it applies basic WTO principles to IP rights, such as the national treatment principle and the MFN principle. The World Trade Organization Trade Related Aspects of Intellectual Property Rights (TRIPS) agreement required signatory nations to raise intellectual property rights (also known as intellectual monopoly privileges). The growth of ecommerce has greatly expanded consumer deals across borders, changing the standard business to business transactions. It is therefore crucial for the online trader to be familiar with relevant national law and also face the possibility that he is liable to be sued in all countries where his website is accessed and goods are purchased.

\section{Other Conventions}

\section{Other International organizations that attempt to harmonize international commercial law are:}

- Unidroit: Important in the area of international financial leasing and sale of goods. Notably UNIDROIT has created the 'Principles of International Commercial Contracts' which in the future could provide the source of lexmercatoria.

- Hague Conference on Private International Law: The organization drafts conventions in the field of private international law.

- Icc: Influential in harmonizing international contract terms and global arbitration practices.

- International Conventions relevant to international sale of goods include:

- UN Convention on the Limitation Period in the International Sale of Goods 1974

- UNIDROIT Convention on Agency in the International Sale of Goods 1983

- UN Convention on International Bills of Exchange and International Promissory Notes 1988

- UN Convention on Independent Guarantees and Stand-By Letters of Credit 1995

\section{conventions providing base of international commercial litigation, arbitration and dispute settlement}

The resolution of disputes arising from private international commercial transactions may be conducted through international commercial mediation, litigation or arbitration. Some inherent difficulties of international litigation include the reluctance to litigate in a foreign court due to unfamiliarity or potential bias and issues of enforcement of a foreign judgment. To overcome this, international commercial arbitration has become a widespread means of solving international commercial disputes. Like mediation, arbitration is a private dispute resolution process pursuant to an agreement between parties. The arbitrator or arbitral panel derives their authority and jurisdiction from the commercial agreement and their decision is prima facie binding. Arbitration is divided into institutional and ad hoc arbitration.

- Institutional Arbitration is conducted through an organization, such as the ICC (International chambers of commerce). The organization governs the arbitral process through a set of rules and administrative structures. Resorting to the institution is typically determined by terms of the commercial contract between parties.

- Ad hoc Arbitration occurs where parties have not specifically made reference to arbitral institution in the contract but agree to submit their dispute to arbitration. Parties can agree to arbitrate according to a statute governing arbitration in the State of one contracting party; or according to an independent set of arbitral rules, such as the UNCITRAL Model Law on International Commercial Arbitration. These rules provide coverage of international commercial arbitration and parties do not need to settle on the arbitration rules (Castellani, 2011).

- International conventions or customs govern international sale of goods contracts, depending on the terms of the sale contract. In the absence of an international convention, domestic law applies. The 'conflict of 
laws' governs which domestic law applies under the principles of private international law. This refers to a situation where the application of respective domestic laws in a commercial dispute can produce very different outcomes. Private law is crucial to international commercial transactions by establishing whether a contract exists; rights and obligations between parties; and the extent of liability if the contract is not performed.

- Disputes between governments in relation to the design and implementation of trade measures: A key role of the WTO in international commercial law is the dispute settlement mechanism for trade disputes. The DSU provides a comprehensive set of rules and procedures to implement each party's obligations under the WTO Agreement, either in isolation or in combination with an agreement between parties. Another important feature is the WTO TPRM which examines a member's trading policies to determine whether they have potential adverse effects on other member states.

- For members of the EU the Rome Convention provides if the parties have not made a clear choice of law then the contract will be governed by the law of the country who carries out performance of the contract. In consumer contracts the Brussels Convention gives the consumer the right to sue in local courts. N.B. This will have profound effects for online traders who may be liable to be sued in any EU state their products are traded in. Enforcement of judgments are recognized automatically in the EU since all states are members of the CISG (Moss, 2005).

- Most prominent in the area of dispute settlement in international trade law is the WTO dispute settlement system. The WTO dispute settlement body is operational since 1995 and has been very active since then with 369 cases in the time between 1 January 1995 and 1 December 2007. Nearly a quarter of disputes reached an amicable solution, in other cases the parties to the dispute resorted to adjudication. The WTO dispute settlement body has exclusive and compulsory jurisdiction over disputes on WTO law (Article 23.1 Dispute Settlement Understanding) (Van den Bossche, 2008).

\section{Discussion}

By studying the concept of international commercial law as well as formation, regulation and enforceability of international contractual relationships; we could compare the positive and negative effects of existence of the international conventions and rules governing organizations:

\section{Arguments in support}

- By ensuring common standards in different nations, conventions promote international trade development.

- Contracting parties have greater confidence when dealing with a foreign party.

- Such uniformity may result in lower costs since: the time spent deciding which law should govern the transaction is reduced and there will be no need to spend time and money attempting to discover the relevant rules prevailing in another jurisdiction.

\section{Arguments against}

- Uniformity is continuously hindered since national courts frequently adopt divergent approaches to their interpretation.

- Conventions lack clarity and certainty since they are drafted in the form of multi-cultural promises aiming to secure maximum agreements.

- The commercial world is constantly altering and the law must adapt to the market's changing needs if it seeks to efficiently facilitate trade.

- An international code which is difficult to amend is unlikely to meet the demands of traders.

Another notablething is the internationalization of contract law and its enforceability; there are two types of basic international laws, ones which are non-binding statements of principle or model contracts framed by international trade governing organizations and secondly which are binding or become mandatory against the choice of contracting parties and international trade communities.

A notable example of the first category is provided by the Institute for the Unification of Private Law which published a statement of Principles for International Commercial Contracts. These principles are contained in 120 articles which are not intended to be imposed upon the commercial community as mandatory rules, which is their biggest weakness since they can be ignored or amended by contracting parties, but seek to bring about harmonization through persuasion. As non-binding principles they serve as guidelines which it is hoped, will be adopted by contracting parties worldwide as well as by national legislators in the aim of updating their international commercial contracts. The Unidroit contracts are similar to other standard form contracts such as INCOTERMS a set of standard trade terms sponsored by the International Chamber of Commerce. Nonbinding principles remain an uncertain method of achieving uniformity.

Being this the reason it is often argued that the international community is in need of greater mandatory rules. The most notable example of an international convention in the second category is provided by the United 
Nations Convention on Contracts for the International Sale of Goods (CISG). Once it has been ratified by the state, the convention applies to all contracts falling within its scope, covering contracts for the international sale of goods.

Therefore the struggle to frame mandatory and uniform international trade and contract laws is still in progress. Although the system faces several issues because of diverse National laws of several states, nevertheless the existing mandatory uniform rules and guidelines for international communities are making the trade and contracts safer and better for transnational commercial communities.

\section{Bibliography}

[1]. Emery, C. (March 2016). International Commercial Contracts - Lickbarrow v Mason (1787) 2 Term Rep 63, 73, Buller J. GlobaLex. Retrieved from:

[2]. http://www.nyulawglobal.org/Globalex/International_commercial_contracts.html\#Introduction, accessed on January 29, 2017

[3]. Gilligan, C., \&Hird, M. (2012). International marketing: strategy and management (Vol. 17). Routledge.

[4]. Peace Palace Library Research Guides- Introduction to International Contracts Law. Retrieved from:

https://www.peacepalacelibrary.nl/research-guides/national-law/international-contracts/, accessed on January 29, 2017

[5]. Schmitthoff, C. M. (1961). International business law: a new Law Merchant. Current Law and Social Problems, $2,129$.

[6]. Levi, M. D. (2009). International Finance 5th Edition. Routledge.

[7]. Buckley, A. (2004). Multinational finance. Pearson Education.

[8]. Methods of Payment in International Trade. Retrieved from: http://www.export.gov/tradefinanceguide/eg_main_043221.asp, accessed on 22 January 2017.

[9]. World Trade Organization (July 1986), The Text of The General Agreement on Tarriffs and Trade. Retrieved from: https://www.wto.org/english/docs_e/legal_e/gatt47_e.pdf, accessed on January 29, 2017

[10]. Ziegel, J. S. (Ed.). (1998). New Developments in International Commercial and Consumer Law: Proceedings of the 8th Biennial Conference of the International Academy of Commercial and Consumer Law. Bloomsbury Publishing.

[11]. Gessner, V., \&Budak, A. C. (Eds.). (1998). Emerging legal certainty: empirical studies on the globalization of law. Ashgate Pub Limited.

[12]. Lista, A. (2016). International Commercial Sales: The Sale of Goods on Shipment Terms. Taylor \& Francis.

[13]. 11United Nations Economic and Social Commission for Asia and Pacific (ESCAP)- Legal Publication, Page 4. Retrieved from: http://www.unescap.org/sites/default/files/pub_2489_ch1.pdf, accessed on January 29, 2017

[14]. Pryles, Waincymer, J. \& Martin, D. (2004). International Trade Law. Page 74

[15]. Erdem, E. (1991). United Nations Convention on Contracts for the International Sale of Goods (Vienna Sale Convention). Banka Huk. Dergisi, 16, 35. Retrieved from: http://www.uncitral.org/uncitral/en/uncitral_texts/sale_goods/1980CISG.html, accessed on 22 January 2017

[16]. United States Department of Commerce, 'The U.N. Convention on Contracts for the International Sale of Goods'. Retrieved from: http://www.osec.doc.gov/ogc/occic/cisg.htm, accessed on 24 January 2017.

[17]. Initiative Objectives. Retrieved from: https://www.ppi-ebrd-uncitral.com/index.php/key-initiative-objectives, accessed on 26 January 2017.

[18]. United Nations Commission on International Trade Law (UNCITRAL) (2013), A Guide to UNCITRAL, Page 2. Retrieved from: http://www.uncitral.org/pdf/english/texts/general/12-57491-Guide-to-UNCITRAL-e.pdf, accessed on January 29, 2017

[19]. Felemegas, J. (2000). The United Nations Convention on contracts for the international sale of goods: article 7 and uniform interpretation (Doctoral dissertation, University of Nottingham).

[20]. About UNCITRAL. Retrieved from: http://www.uncitral.org/uncitral/en/about_us.html, accessed on 25 January 2017.

[21]. United States Department of Commerce, 'The U.N. Convention on Contracts for the International Sale of Goods'. Retrieved from: http://www.osec.doc.gov/ogc/occic/cisg.htm, accessed on 24 January 2017.

[22]. Felemegas, J. (2000). The United Nations Convention on contracts for the international sale of goods: article 7 and uniform interpretation (Doctoral dissertation, University of Nottingham).

[23]. Schlechtriem, P. (2005). Requirements of Application and Sphere of Applicability of the CISG. Victoria U. Wellington L. Rev., 36, 781.

[24]. Lookofsky, J. M. (1991). Loose Ends and Contorts in International Sales: Problems in the Harmonization of Private Law Rules. The American Journal of Comparative Law, 39(2), 403-416.

[25]. Zeller, B. (2008). CISG and the unification of international trade law. Routledge.

[26]. International Chamber of Commerce (ICC) (January, 2017), International Commercial Terms (INCOTERMS). Retrieved from: https://www.searates.com/reference/incoterms/, accessed on January 29, 2017

[27]. International Chamber of Commerce (ICC) (January 2011), International Commercial Terms (INCOTERMS). Retrieved from: https://www.searates.com/reference/incoterms/, accessed on January 29, 2017

[28]. World Trade Organization - UNDERSTANDING THE WTO: BASICS. Retrieved from: https://www.wto.org/english/thewto_e/whatis_e/tif_e/fact4_e.htm, accessed on 25 January 2017.

[29]. Fernando, A. C. (2011). Business environment. Pearson Education India.

[30]. Meltzer, J. (2011). The Challenges to the World Trade Organization: It's all about legitimacy. Brookings Institution.

[31]. Van den Bossche, P. (2008). The law and policy of the World Trade Organization: text, cases and materials. Cambridge University Press. Page 80.

[32]. Chaudhary, M. A. \& Chaudhary, G. (2009).Global EncyclopaediaOf International Economics And Taxation. Page 307.

[33]. The GATT years: from Havana to Marrakesh, World Trade Organization. Retrieved from: https://www.wto.org/English/thewto_e/whatis_e/tif_e/fact4_e.htm, accessed on 25 January 2017.

[34]. Understanding the World Trade Organisation: Basics, Principles of the trading system. Retrieved from: https://www.wto.org/english/thewto_e/whatis_e/tif_e/fact2_e.htm, accessed on January 29, 2017

[35]. International Law \& Contracts. Retrieved from: http://www.internationaltrade.co.uk/articles_print.php?CID=\&SCID=\&AID=30, accessed on 23 January 2017.

[36]. International Trade U.K., International Law \& Contracts, The Legal Dimension of International Trade. Retrieved from: http://www.internationaltrade.co.uk/articles_print.php?CID=17\&SCID=\&AID=30, accessed on January 29, 2017

[37]. International Law \& Contracts. Retrieved from: http://www.internationaltrade.co.uk/articles_print.php?CID=\&SCID=\&AID=30, accessed on 23 January 2017. 
[38]. Castellani, L. G. (2011). The contribution of UNCITRAL to the harmonization of international sale of goods law besides the CISG. Annals Fac. L. Belgrade Int'l Ed., 28.

[39]. World Trade Organisation- Annex 2- Understanding on rules and procedures governing the settlement of disputes. Retrieved from: https://www.wto.org/english/docs_e/legal_e/28-dsu.doc, accessed on January 29, 2017

[40]. Moss, S. (2005). The Why the United Kingdom Has Not Ratified the CISG. JL \& Com., 25, 483.

[41]. Understanding the WTO: Settling Disputes- A Unique Contribution. Retrieved from: https://www.wto.org/english/thewto_e/whatis_e/tif_e/disp1_e.htm, accessed on January 26, 2017

[42]. Van den Bossche, P. (2008). The law and policy of the World Trade Organization: text, cases and materials. Cambridge University Press. Page 169. 